\title{
VÝZNAM ROZSUDKŮ SOUDŮ ČR PŘI ZAJIŠTĚNÍ NÁROKU゚ KLIENTU゚ V PŘÍPADĚ ÚPADKU CESTOVNÍ KANCELÁŘE
}

\author{
KLÁRA DVOŘÁKOVÁ (ROZENÁ HAVLÍČKOVÁ)
}

\begin{abstract}
Influence of Judgments of Czech Courts for Ensuring Demands of Clients in Case of Bankruptcy of Tour Operators

The article documents the case-law of Czech courts from 2012 to 2015 related to insurance in case of bankruptcy of tour operators. It draws attention to the shift in the interpretation of the specific provisions of the Act No. 159/1999 Coll., on Tourism concerning the extent of the recovery of clients' damages caused by the bankruptcy of the tour operator. It describes the attitude of the courts to dealing with many cases based on similar facts and law. It also focus on the effects of the case-law on the conduct of the clients, tour operators, travel agents and insurance companies. The author deems to share her experience as an attorney representing clients in the court proceedings against insurance companies.
\end{abstract}

Key words: tour operator, bankruptcy, insurance, case-law

Klíčová slova: cestovní kancelár̆, úpadek, pojištění, judikatura

DOI: $10.14712 / 23366478.2016 .40$

Čl. 7 směrnice Rady 90/314/EHS ze dne 13. 6. 1990 o souborných službách pro cesty, pobyty a zájezdy (dále jen „směrnice 90/314“) ukládá členským státům zajistit, aby organizátor nebo prodejce, který je stranou smlouvy o zájezdu, předložili dostatečné záruky pro zajištění vrácení vložených prostředků a pro návrat spotřebitele $\mathrm{v}$ príípadě platební neschopnosti nebo úpadku. Za účelem provedení uvedené unijní povinnosti do práva ČR byl do zákona č. 159/1999 Sb., o některých podmínkách podnikání a o výkonu některých činností v oblasti cestovního ruchu (dále jen „zákon č. 159/1999 Sb.") vnesen institut pojištění záruky pro př́ípad úpadku. Pojištění záruky pro př́pad úpadku je tedy nástroj, který má v ČR chránit klienty cestovních kanceláŕí před ztrátou jejich finančních prostředků $\mathrm{v}$ případě úpadku cestovní kanceláře, eventuálně má také zajistit jejich návrat ze zájezdové destinace zpět domů.

Série úpadků cestovních kanceláŕí v letech $2011^{1}$ a $2012^{2}$ upozornila na to, že text zákona č. 159/1999 Sb. nepodává jednoznačnou odpověd' na to, zda je pojišt'ovna, v př́ípadě, že je cestovní kancelář tzv. podpojištěna, ${ }^{3}$ povinna uhradit klientovi cestovní kanceláře v úpadku (dále jen „klient“ nebo „zákazník“) pojistné plnění ve výši

\footnotetext{
V létě 2011 se ocitla v úpadku cestovní kanceláŕ I. Parkam Holidays.

V roce 2012 následovaly cestovní kanceláře BG Travel, Honza, GLOBALTOUR a některé další.

O podpojištění ve smyslu $§ 2854$ Občanského zákoníku hovoříme tehdy, pokud je pojistná částka v době pojistné události nižší než pojistná hodnota pojiššeného majetku.
} 
plné ceny zaplacené za zakoupení zájezdu, nebo zda je oprávněna pojistné plnění krátit úměrně k výši sjednaného tzv. limitu pojistného plnění.

Výkladová nejasnost dala vzniknout právnímu sporu mezi klienty a pojišt'ovnami, který vyústil v podání desítek, ne-li více než sta, klientských žalob na pojištovny. ${ }^{4}$ Přestože některá soudní ř́izení již v mezidobí byla pravomocně skončena, ${ }^{5}$ právní spor v pozadí není ještě ani na podzim roku 2015 ukončen.

Cílem článku je zaprvé, popsat, jak se v letech 2012 až 2015 v rozsudcích soudů ČR (dále jen „rozsudky“) vyvíjel přístup k výkladu ustanovení zákona č. 159/1999 Sb. o pojištění záruky pro případ úpadku, zadruhé, upozornit, jak se soudy vypořádaly s větším množstvím žalob o skutkově a právně obdobné (ne-li totožné) věci, a zatřetí, upozornit jaké konkrétní dopady měla $\mathrm{v}$ tomto př́padě rozhodnutí soudů na jednání dotčených subjektů cestovního ruchu, tj. zákazníků, cestovních kanceláríí, prrípadně jejich prodejců, a pojištoven. Cílem článku není provést zamyšlení de lege lata nebo de lege ferenda, nýbrž popsat stav věcí a událostí. I proto je v článku hojně využíváno citací z rozsudků. Jedná se převážně o rozsudky nižších soudů, jejichž texty jsou jinak obtížně dohledatelné. Za pár let by snad článek mohl mít $\mathrm{z}$ historického pohledu dokumentační hodnotu. Vzhledem $\mathrm{k}$ tomu, že mnozí z možných čtenářu nejsou právníci, jsou zařazeny i často kompletní výňatky z některých právních předpisů a dokumentů.

Autorka zastupuje $\mathrm{v}$ probíhajících soudních sporech klienty cestovních kancelárí. V článku je proto pracováno také $\mathrm{s}$ dokumenty $\mathrm{z}$ klientských spisů získaných $\mathrm{v}$ souvislosti se zastupováním v jednotlivých kauzách. Článek představuje argumentaci obou stran sporu, ovšem není, a to zejména v jeho závěrečném zhodnocení, zcela neutrální.

\section{UNIJNÍ RÁMEC PRÁVNÍ ÚPRAVY ZAJIŠTĚNÍ KLIENTA PRO PŘÍPAD ÚPADKU CESTOVNÍ KANCELÁŘE}

Argumentační logiku rozsudků by nebylo možné dobře uchopit bez nastínění unijního rámce právní úpravy zajištění pro př́ípad úpadku a bez upozornění na v letech 2012 až 2015 platné a účinné znění relevantních ustanovení zákona č. 159/1999 Sb. Unijnímu základu, který je klíčový v argumentaci obou stran sporu, bude věnován tento oddíl. V následujícím oddílu bude popsáno platné a účinné znění relevantních ustanovení zákona č. 159/1999 Sb. ${ }^{6}$

Čl. 7 směrnice 90/314 ukládá členským státům povinnost zajistit, aby organizátor nebo prodejce, který je stranou smlouvy o zájezdu, předložili dostatečné záruky pro

4 Autorka sama podala jménem svých klientů od roku 2012 celkem 34 žalob.

5 Z 34 žalob, které jménem svých klientů podala autorka, bylo ke dni sepsání tohoto článku pravomocně skončeno 7 řízení. Ve prospěch klientů jde o rozsudek Obvodního soudu pro Prahu 2 ve věci č.j. 22 C 68/2012-90 ze dne 26. 3. 2013, rozsudek Městského soudu v Praze č.j. 51 Co 38/2014 - 165 ze dne 28. 3. 2014, rozsudek Městského soudu v Praze č.j. 15 Co 471/2013-127 ze dne 18. 2. 2014 a rozsudek Obvodního soudu pro Prahu 8 č.j. 12 C 230/2013-227 ze dne 24. 9. 2015. Proti klientům jde o rozsudek Obvodního soudu pro Prahu 2 č.j. 13 C 129/2012-91 ze dne 5. 3. 2014, rozsudek Městského soudu v Praze č.j. 72 Co 79/2014-164 ze dne 21. 5. 2014 a rozsudek Městského soudu v Praze č.j. 53 Co 302/2014 - 252 ze dne 20. 11. 2014.

6 Tyto oddíly autorka použila z př́slušné kapitoly své knihy HAVLÍČKOVÁ, K. - KRÁLOVÁ, R.: Cestovní právo. Praha, 2015, s. 334. 
zajištění vrácení vložených prostředků a pro návrat spotřebitele v případě platební neschopnosti nebo úpadku.

K čl. 7 směrnice 90/314 existuje početná judikatura SDEU. ${ }^{7}$ Tato judikatura podává závazný výklad čl. 7 směrnice, který jsou povinny respektovat rovněž národní soudy při výkladu těch ustanovení vnitrostátních předpisů, které směrnici provádějí do vnitrostátního práva jednotlivých členských států. Ve světle zmíněné judikatury je cílem směrnice 90/314 zabezpečit vysokou úroveň ochrany spotřebitelů a základním cílem čl. 7 konkrétně zajistit, aby v případě platební neschopnosti nebo úpadku organizátora byl zaručen návrat spotřebitele a vrácení jím vložených prostředků. ${ }^{8}$

SDEU již také specifikoval, že směrnice 90/314 nespojuje se zárukou pro zajištění vrácení vložených prostředků a pro návrat spotřebitele v případě platební neschopnosti nebo úpadku žádnou zvláštní podmínku týkající se důvodů platební neschopnosti organizátora cesty. Ani takové okolnosti, jako je nerozvážné jednání organizátora cesty nebo výskyt mimořádných nebo nepředvídatelných událostí, nepředstavují překážku pro vrácení vložených prostředků a pro návrat spotřebitelů ve smyslu čl. 7 směrnice 90/314. ${ }^{9}$

Již od 15. 6. 1999, kdy byl vyhlášen rozsudek ve věci Rechberger, C-140/97, je rovněž zřejmé, že účinnou zárukou je pouze taková záruka, která zajišt'uje navrácení všech zákazníkem zaplacených finančních prostředků:

„(63) V preambuli směrnice ani ve znění čl. 7 nic nenasvědčuje tomu, že by záruka požadovaná tímto článkem mohla být omezena...

(64) Proto je třeba stanovit, že o náležitou transpozici povinností podle čl. 7 směrnice se jedná tehdy, pokud, bez ohledu na podrobnosti prijatých prováděcích pravidel bylo dosaženo cíle, kterým je poskytnout spotřebiteli účinnou záruku navrácení všech jím zaplacených finančnich prostředků a zajištění repatriace v př́padě platební neschopnosti nebo úpadku organizátora cesty." 10

Z usnesení SDEU ze dne 16. 1. 2014, Ilona Baradics a další, C-430/13, konečně vyplývá, že pouze vnitrostátní soud je povolán k tomu, aby posoudil, zda konkrétní vnitrostátní právní úprava je účinnou zárukou navrácení všech zaplacených finančních prostředků a repatriace, tj. zda dosahuje účelu stanoveného čl. 7 směrnice:

„Článek 7 smérnice 90/314/EHS z 13. 6. 1990 o souborných službách pro cesty, pobyty a zájezdy je třeba vykládat v tom smyslu, že brání takové vnitrostátní právní úpravě, jejíž podrobná pravidla nedosahuji výsledku, kterým je zajistit, že spotřebitel obdrži účinnou záruku navrácení v̌̌ech zaplacených finančních prostředků a repatriaci v prípadě úpadku cestovní kanceláře. Je úkolem vnitrostátního soudu stanovit, zda tak je tomu v prípadě vnitrostátni právni úpravy, která je předmětem před ním probíhajícího sporu.

Článek 7 směrnice 90/314/EHS je třeba vykládat v tom smyslu, že členské státy nemají žádný prostor pro uvážení, pokud jde o rozsah rizik, která mají být pokryta zá-

\footnotetext{
7 Srov. rozsudek SDEU Dillenkofer, ve spojené věci C-178/94, C-179/94, C-188/94, C-189/94 a C-190/94, EU:C:1996:375; rozsudek SDEU Verein für Konsumenteninformation, C-364/96, EU:C:1998:226, rozsudek SDEU Rechberger, C-140/97, EU:C:1999:306, rozsudek SDEU Blödel Pawlik, C-134/11, EU:C:2012:98, rozsudek SDEU Ilona Baradics a dalši, C-430/13, EU:C:2014:32.

8 Viz rozsudek SDEU Blödel Pawlik, C-134/11, EU:C:2012:98, body 21 a 23.

9 Viz tamtéž, body 20 a 24.

10 Viz rozsudek SDEU Rechberger, C-140/97, EU:C:1999:306, body 63 a 64.
} 
rukou, kterou poskytuje cestovni kancelár ve prospěch zákazníků. Je na vnitrostátním soudu, aby stanovil, zda kritéria stanovená členským státem za účelem určeni částky záruk, mají za cíl nebo za účinek omezení rizik, která mají být zárukou pokryta, a v takovém př́padě by byla jednoznačně v rozporu se závazky podle směrnice 90/314/EHS a predstavovala by dostatečně závažné porušeni unijniho práva, které, v prípadě zjištění prímého vztahu přičiny a následku, by zakládalo odpovědnost dotčeného členského státu." (neoficiální prèklad).

Z čl. 7 směrnice $90 / 314$ a z citované judikatury pro ČR vyplývají zcela konkrétní povinnosti, na které ČR reagovala $v$ roce 1999 zavedením pojištění záruky pro př́ípad úpadku a jeho zakotvením v $§ 6$ až 8 zákona č. 159/1999 Sb.

Podle důvodové zprávy k zákonu č. 159/1999 Sb. si zavedení právní úpravy povinného pojištění záruky v právním řádu ČR vynutily:

- zaprvé, povinnost ČR plnit závazky vyplývající z členství v Evropské unii, konkrétně povinnost transponovat řádně a včas do právního rádu směrnici $90 / 314$,

- zadruhé, specifické rysy oblasti cestovního ruchu, konkrétně potřeba zvýšení ochrany spotřebitele v oblasti cestovního ruchu v ČR a potřeba zkvalitnění služeb stávajících cestovních kanceláŕí. ${ }^{11}$

\section{PLATNÁ A ÚČINNÁ ÚPRAVA POJIŠTĚNÍ PRO PŘÍPAD ÚPADKU V ZÁKONĚ Č. 159/1999 SB.}

Právní úprava povinného pojištění záruky obsažená v $§ 6$ až 8 zákona č. 159/1999 Sb. zní a rovněž po celé období let 2012 až 2015 zněla takto:

11 V obecné části důvodové zprávy k zákonu č. 159/1999 Sb. se konkrétně uvádí: „Usnesením č. 151 ze dne 15. 3. 1995 vzala vláda na védomi harmonogram opatřeni k postupnému sbližování právních préedpisù České republiky s právem ES. ... Součástí tohoto harmonogramu byl i úkol predložit návrh právní úpravy, $v$ niž by byla zapracována směrnice 90/314/EHS z 13. 6. 1990 o hotových programech na cesty, prázdniny a zájezdy (dále jen ,Směrnice"). Tato Smérnice je zásadním dokumentem pro ochranu spotřebitele na úseku cestovního ruchu a mimo jiné stanovi i povinnost státu zabezpečit garance spotřebiteli při platební neschopnosti cestovnich kanceláří. ...Vzhledem $k$ negativním jevưm v oblasti cestovního ruchu (úpadky rady cestovnich kanceláří, jejichž důsledky se projevily zejména v zahraničí a poškodily dobré jméno České republiky) je na jedné straně problém garanci pro spotřebitele i stát velmi aktuální, na straně druhé se jedná o zcela novou problematiku a dosažení nutného konsensu v otázce formy a rozsahu těchto garancí je velmi problematické. Ministerstvo po velmi obtižných jednánich a po vyloučení řešení, která byla z různých důvodi̊ neprůchodná, zvolilo formu pojištění v rozsahu upraveném v textu zákona. ... Př́ práci na návrhu zákona vycházelo ministerstvo ze tř́i základnich požadavkư, které spolu velmi úzce souvisí: implementace Směrnice, zvýšeni ochrany spotřebitele v oblasti cestovního ruchu v České republice a zkvalitněni služeb stávajicich cestovnich kancelárí. ... Na základě rozsáhlé novely živnostenského zákona v roce 1995 se na základě obecného požadavku liberalizace přistupu k podnikání stala z pưvodni koncesované živnosti, cestovni kancelár ‘ živnost volná. Tato skutečnost sice na jedné straně způsobila, že došlo k rozvoji v tomto oboru podnikání, na straně druhé však zkušenosti, zejména ze sezóny 1997, ukazuji, že naprostá deregulace a volnost podnikáni má závažné negativní důsledky. Jedná se konkrétně o problémy spojené s repatriací zákazniků cestovních kancelárí, ponechaných bez pomoci a prostředků v zahraniči a s vrácením peněžnich prostředků složených zákazníkem za účelem nerealizované cesty v důsledku platební neschopnosti cestovní kanceláre. K tomu přistupuje nejednotnost postupu cestovnich kancelář́ při uzaviráni smluv, nejednotnost cestovnich podmínek, presouváni odpovédnosti cestovnich kancelárí na zákazníka (zákazník uzavirá své individuálni pojištěni pro př́pady škod, za které odpovidá cestovni kancelár̆) a dezorientace zákazníka, s kým vlastně uzavřel smlouvu v př́padě, kdy zájezd cestovni kanceláře je prodáván jiným prodejcem.“ 


\section{„Povinné pojištění záruky}

$\S 6$

(1) Cestovni kanceláŕ je povinna sjednat pojištěni záruky pro př́pad úpadku cestovní kanceláre, na základě něhož vzniká zákaznikovi pojištěnému cestovni kanceláři právo na plnění v prípadech, $k d y$ cestovni kancelár $z$ důvodu svého úpadku

a) neposkytne zákazníkovi dopravu z mista pobytu v zahraničí do České republiky, pokud je tato doprava součástí zájezdu,

b) nevrátí zákazníkovi zaplacenou zálohu nebo cenu zájezdu v prípadě, že se zájezd neuskutečnil, nebo

c) nevrátí zákazníkovi rozdíl mezi zaplacenou cenou zájezdu a cenou částečně poskytnutého zájezdu v př́padě, že se zájezd uskutečnil pouze zčásti.

(2) Neni-li tímto zákonem stanoveno jinak, ř́dí se povinné pojištěni záruky př́slušnými ustanoveními zvláštního zákona.

(3) Pojistná smlouva musí být sjednána tak, aby se pojištění vztahovalo na veškeré zájezdy prodané $v$ době platnosti pojistné smlouvy, ledaže cestovní kancelár̆ uzavře pojistnou smlouvu novou. Okamžikem prodeje zájezdu se rozumi okamžik uzavření cestovni smlouvy. Ujednáni pojistné smlouvy, která jsou v rozporu s podmínkou podle věty prvé, jsou neplatná.

(4) Pojištovna předá cestovní kanceláři kromě pojistky rovněž doklady určené zákazníkům, které musi obsahovat informace o uzavřeném pojištění, zejména označeni pojištovny, podminky pojištění a zpưsob oznámeni pojistné události; cestovní kancelár̆ je povinna predat tento doklad zákazníkovi současnè s cestovní smlouvou.

$\S 7$

(1) V prípadě, že zákazníkovi nebude poskytnuta doprava z mista pobytu v zahraniči do České republiky, poskytne pojištovna plněni zabezpečením dopravy z mista pobytu do České republiky, včetně nezbytného ubytováni a stravování do doby odjezdu i v př́padě, že se pojištovně nepodaři do 12 hodin po oznámeni škodné události průkazně ověřit u odpovédného zástupce cestovni kanceláře, že došlo k pojistné události podle $\S 6$ odst. 1 písm. a) tohoto zákona. V př́padě, že se následným šetřením pojištovny neprokáže, že došlo k pojistné události, je cestovni kancelár povinna uhradit pojištovně to, co za ni pojištovna plnila. Zajistí-li si zákaznik dopravu včetně nezbytného ubytování a stravování na vlastni náklady, poskytne mu pojištovna peněžni plnění pouze do výše, jakou by musela vynaložit, pokud by dopravu, ubytováni a stravování zajištovala sama. (2) Pojistné plnění podle odstavce 1 poskytne pojišstovna okamžitě po ověreni pravdivosti oznámeni pojistné události. Pro oznámení pojistné události podle odstavce 1 se nevyžaduje písemná forma.

(3) Pojištovna není oprávněna odmitnout pojistné plnění nebo snižit jeho výši v případě, dozví-li se po pojistné události, že cestovni kancelár vědomě poskytla nepravdivé nebo neúplné podklady, které byly pro uzavřeni pojištěni podstatné. Pojištovna je však v tomto prípadě oprávněna domáhat se náhrady škody na cestovni kancelárí.

$\S 8$

(1) Pojištěni lze sjednat pouze u pojištovny, která je podle zvláštního právního predpisu oprávněna provozovat pojištění záruky. Pojistné podmínky pro povinné pojištěni záruky je pojištovna povinna predložit České národní bance na její vyžádáni ke kontrole. Čes- 
ká národni banka spolupracuje při kontrole pojistných podminek pro pojištěni záruky $s$ ministerstvem.

(2) Cestovni kancelár je povinna sjednat pojištění v rozsahu § 6 na pojistnou částku minimálně $30 \%$ ročních plánovaných tržeb z prodeje zájezdů nebo v př́padě, že tyto tržby maji být nižši než tržby v predchozím roce, na pojistnou částku minimálně $30 \%$ těchto tržeb v predchozím roce.

(3) Cestovní kancelár je povinna před uzavřením pojistné smlouvy a kdykoli v době trvání pojištěni umožnit pojištovně na jeji žádost př́stup ke všem dokladům, které souviseji s pojištěním zájezdì, a podat $k$ nim vysvětlení.

(4) Nároky zákazníka, které mu vznikly proti cestovni kanceláři $v$ di̊sledku nesplnění cestovni smlouvy v prípadech uvedených $v \S 6$ odst. 1, přecházejí na pojištovnu, a to až do výše plněni, které mu pojištovna poskytla.

(5) Všeobecné pojistné podmínky stanoví, jakou částkou se cestovní kancelár̆ podilí na pojistné události, zpưsob jeji úhrady pojištovně a zúčtováni vioči cestovni kancelářri, bližši podmínky jejího použití a připady, kdy je pojištovna povinna nepoužitou částku cestovni kancelári vrátit. Vyšse částky, kterou se cestovni kancelár podilí na plnění z pojistné události, nesmi být nižši než $2 \%$ ročnich plánovaných tržeb z prodeje zájezdiu. V̌seobecné pojistné podmínky mohou omezit př́pady a výši pojistného plnění pouze v rozsahu, vjakém jsou omezeny povinnosti cestovni kanceláre vi̊či zákazníkovi zvláštním právním předpisem.

(6) O zániku pojištění jsou cestovní kancelár i pojištovna povinny neprodleně informovat ministerstvo. Rovněž tak jsou povinny bez odkladu informovat ministerstvo o všech skutečnostech, zejména o závažných nedostatcich ve finančním hospodaření cestovní kanceláré, pokud mohou vést $k$ zániku pojištění. Pojištovna je rovněž povinna informovat ministerstvo o vzniku pojistné události a o poskytnutém pojistném plněni.““

$\mathrm{K}$ citovanému textu je vhodné doplnit, že $\mathrm{v}$ něm hojně používaný pojem úpadek je definován v 33 zákona č. 182/2006 Sb., o úpadku a způsobech jeho řešení (insolvenční zákon). Jedná se o situaci, kdy dlužník splňuje následující podmínky: zaprvé, má více věritelů, zadruhé, má peněžité závazky po dobu delší 30 dnů po lhủtě splatnosti, a zatřetí tyto závazky není schopen plnit (dále jen „platební neschopnost“). Má se za to, že dlužník není schopen plnit své peněžité závazky, jestliže a) zastavil platby podstatné části svých peněžitých závazků, b) je neplní po dobu delší tří měsíců po lhůtě splatnosti, c) není možné dosáhnout uspokojení některé ze splatných peněžitých pohledávek vůči dlužníku výkonem rozhodnutí nebo exekucí, nebo d) nesplnil povinnost předložit seznamy uvedené v $§ 104$ odst. 1 insolvenčního zákona, kterou mu uložil insolvenční soud. Dlužník, který je právnickou osobou nebo fyzickou osobou - podnikatelem, je v úpadku i tehdy, je-li předlužen. O předlužení jde tehdy, má-li dlužník více věřitelů a souhrn jeho závazků převyšuje hodnotu jeho majetku.

Úpadek je podle insolvenčního zákona tedy faktický stav. Aby byla aplikována ustanovení zákona o cestovním ruchu o pojištění záruky, stačí, aby se cestovní kanceláŕ fakticky ocitla v úpadku. Konstatování úpadku insolvenčním soudem není nezbytné. ${ }^{12}$

$12 \mathrm{~K}$ tomu srov. rozsudek Obvodního soudu pro Prahu 8 č.j. 12C 230/2013-227 ze dne 24. 9. 2015. 
Z citovaných ustanovení zákona o cestovním ruchu plyne, že pokud jde o věcný rozsah plnění, je pojišt'ovna $\mathrm{v}$ př́padě úpadku cestovní kanceláře povinna klientovi poskytnout jako pojistné plnění minimálně:

- dopravu z místa pobytu do ČR, včetně nezbytného ubytování a stravování do doby odjezdu,

- zajistí-li si klient dopravu včetně nezbytného ubytování a stravování na vlastní náklady, poskytnout mu peněžní plnění pouze do výše, jakou by musela vynaložit, pokud by dopravu, ubytování a stravování zajišt'ovala sama,

- zaplacenou zálohu nebo cenu zájezdu v př́padě, že se zájezd neuskutečnil, nebo

- rozdíl mezi zaplacenou cenou zájezdu a cenou částečně poskytnutého zájezdu v případě, že se zájezd uskutečnil pouze zčásti.

\title{
VÝVOJ ROZSUDKU゚ V LETECH 2012 AŽ 2015
}

\author{
PRVNÍ ROZSUDEK - PROKLIENTSKÝ ROZSUDEK
}

Prvním soudem, který na základě klientské žaloby nařídil jednání ve věci a hned na prvním jednání také rozhodl, byl Obvodní soud pro Prahu 2 ve věci sp. zn. 22 C 68/2012. Soud byl povolán rozhodnout o zaplacení doplatku pojistného plnění ve výši 9596,- Kč s př́islušenstvím. Šlo tedy o tzv. bagatelní věc, u níž není proti rozsudku odvolání př́ípustné.

Klient před soudem tvrdil, že má na základně pojistné smlouvy, která byla v roce 2011 uzavřena mezi stěžovatelkou a cestovní kanceláří, nárok na zaplacení plné ceny zájezdu, protože ujednání v pojistné smlouvě, které by bránilo tomu, aby mu byla jako pojistné plnění uhrazena plná cena zájezdu, je absolutně neplatné pro rozpor se zákonem č. 159/1999 Sb. ve spojení se zákonem č. 40/1964 Sb., občanský zákoník.

Klient zdůrazňoval, že povinné pojištění záruky bylo do právního řádu ČR zavedeno, aby chránilo zákazníka, který s cestovní kanceláŕí uzavřel pojistnou smlouvu, v př́ipadě, že se cestovní kanceláŕ dostane do úpadku. V souladu s povinnostmi, které pro ČR vyplývají z čl. 7 směrnice 90/314, tak, jak jsou vyloženy judikaturou SDEU, bylo úmyslem ČR upravit pojištění záruky v právním řádu takovým způsobem, aby zákazníci získali v př́ípadě úpadku zpět všechny prostředky, které cestovní kanceláři na základě cestovní smlouvy zaplatili. Česká republika tohoto cíle dosáhla tak, že pro oblast pojištění záruky specificky zakotvila zákonnou povinnost pojišstovny vyplatit zákazníkům cestovní kanceláře, se kterou uzavřela pojistnou smlouvu, pojistné plnění v plné výši jejich nároků z cestovní smlouvy, která byla cestovní kanceláŕí úpadkem porušena. Jedná se o kogentní povinnost uloženou zákonem, kterou pojišt'ovny nemohou s ohledem na ustanovení § 8 odst. 5, poslední věta, zákona č. 159/1999 Sb., v pojistné smlouvě, resp. všeobecných pojistných podmínkách, vyloučit. $Z$ důvodů existence této povinnosti je s uzavřením pojistné smlouvy pojišt'ovnou spojeno značné pojistné riziko. Toto riziko je přenecháno pojišt'ovně proto, že je jako odborník schopna se s ním vyrovnat. Aby nesení rizika bylo po pojišt’ovně spravedlivé požadovat, přináší zákon č. 159/1999 Sb. několik ochranných institutů, které pojistné riziko pomáhají omezit. Jedná se o prá- 
vo pojišt'ovny vyžádat si před uzavřením pojistné smlouvy a kdykoli v jejím průběhu doklady, které souvisejí s pojištěním zájezdů, a vysvětlení $\mathrm{k}$ nim ( $\$ 8$ odst. 3 zákona č. 159/1999 Sb.); povinnost sjednat si spoluúčast, která nemůže být nižší než zákonem stanovené minimum, a tu poté, co bude pojistné plnění vyplaceno zákazníkům, regresně uplatňovat vůči cestovní kanceláŕi ( 88 odst. 5, první dvě věty, zákona č. 159/1999 Sb.); právo domáhat se na cestovní kanceláři náhrady škody, která pojišt'ovně vznikla tím, že pojistnou smlouvu uzavřela na základě nepravdivých nebo neúplných podkladů, které byly pro uzavření pojištění podstatné ( 7 odst. 3 zákona č. 159/1999 Sb.) a konečně povinnost sjednat si v pojistné smlouvě pojistnou částku, která nesmí být nižší než $30 \%$ ročních plánovaných tržeb z prodeje zájezdů nebo v př́ípadě, že tyto tržby mají být nižší než tržby v předchozím roce, na pojistnou částku minimálně $30 \%$ těchto tržeb v předchozím roce ( 8 odst. 2 č. 159/1999 Sb.). Poslední ochranný institut, pojistná částka, má, s ohledem na existenci zákonné povinnosti poskytnout zákazníkům cestovní kanceláře, která se dostala do úpadku, plnění v celém rozsahu jejich nároků z porušené cestovní smlouvy, význam jen pro vztah mezi pojištovnou a cestovní kanceláří. I př́i překročení pojistné částky je pojišt’ovna z titulu uzavřené pojistné smlouvy povinna plnit v plném rozsahu, jelikož ujednání v pojistné smlouvě, které plnění ve vztahu k zákazníkovi omezuje, je neplatné pro rozpor se zákonem o cestovním ruchu. Při výplatě pojistného plnění vzniká pojištovně pohledávka vůči cestovní kanceláři, která se dostala do úpadku. Popsaná koncepce je možná mimo jiné z toho důvodu, že ustanovení zákona o cestovním ruchu o pojištění záruky jsou speciální $\mathrm{k}$ zákonu o pojistné smlouvě. V pochybnostech o výkladu ustanovení vnitrostátního práva ve smyslu navrhovaném klientem, by měl soud přihlédnout ke své povinnosti vykládat ustanovení vnitrostátních předpisů, která provádějí ustanovení unijního práva, v souladu se smyslem a účelem směrnice $90 / 314$, tzv. eurokonformně.

Pojištovna a klient se v rámci své argumentace přeli především o to, zda ustanovení zákona č. 159/1999 Sb. a ustanovení zákona č. 40/1964 Sb., občanský zákoník ${ }^{13}$ o cestovní smlouvě lze vyložit eurokonformně, aniž by podaný výklad zákonných ustanovení byl výkladem contra legem. Pojišt'ovna tvrdila, že nikoli, přičemž jejím stě̌žjním argumentem bylo tvrzení, že s omezením pojistného plnění horní hranicí počítá ustanovení $\S 28$ odst. 1 a 3 zákona č. 37/2004 Sb., o pojistné smlouvě, přičemž na tento zákon odkazuje ustanovení § 6 odst. 2 zákona č. 159/1999 Sb., podle kterého: „neni-li stanoveno jinak, rídí se povinné pojištěni záruky zákonem o pojistné smlouvě.

Obvodní soud pro Prahu 2 ve svém prvním rozsudku postavil na jisto, že se „zcela ztotožňuje s právním hodnocením učiněným žalobcem, který svůj nárok opirá o citovaná zákonná ustanoveni občanského zákoníku o cestovni smlouvě a zákona o některých podminkách podnikání a o výkonu některých činností v oblasti cestovního ruchu“. Dále pak argumentoval takto:

„Smyslem právní úpravy pojištění záruky za nároky zákazníků cestovních kanceláři je poskytnout jim v př́padè úpadku cestovni kanceláre plněni v takové výši, v jaké by měla povinnost tyto nároky uspokojit samotná cestovni kancelár, kdyby k jejimu úpad-

13 Spory vznikly za účinnosti zákona č. 40/1964 Sb., občanský zákoník, a proto na ně nový občanský zákoník nedopadl. Ze stejného důvodu je všude v textu článku a textu citovaných rozsudků používán pojem „cestovní smlouva“ namísto aktuálního pojmu „smlouva o zájezdu“. 
ku nedošlo. Jakýkoli jiný výklad by totiž vedl k závěru, že dohodou cestovni kanceláře s př́slušnou pojištovnou by sice naoko cestovni kancelár dostála svým zákonným povinnostem, avšak oba subjekty by vyloučily možnost spotřebitele domoci se svých zákonných nároků, a zcela by tak popřely smysl zákona. Soud souhlasís názorem žalobce, že nároky zákazníků z cestovni smlouvy jsou kogentně stanoveny přislušnými ustanoveními občanského zákoníku o cestovní smlouvě, a tato právní úprava je ve vztahu k zákonu o pojistné smlouvě speciální. Dle názoru soudu tak nelze použí omezení pojistného plněni vyplývajici at již z § 28 odst. 1 a odst. 3 zákona o pojistné smlouvě, či pojistných podminek pojišstovny, nebot' soukromoprávni ujednáni dvou podnikatelských subjektů nemůže vést $k$ vyloučeni nebo omezeni zákonných nároki̊ spotřebitele, který navic na toto soukromoprávní ujednáni nemá jakýkoliv vliv. Ujednáni pojišstovny s cestovní kancelárí, které omezuje práva spotřebitele a popírá smysl zákona, je tak ve vztahu ke spotřebiteli neplatné a neúčinné. Jak vyplývá z citovaného ustanoveni § 8 zákona, je zde stanovena povinnost cestovni kancelári sjednat pojištění, přičemž minimální hranice $30 \%$ ročních plánovaných tržeb směruje evidentně $k$ tomu, aby výše pojištěni odpovídala rozsahu podnikáni cestovni kanceláre a nepoškozovala pojištovnu, na druhou stranu z tohoto ustanoveni nelze dovodit, že by při nesplněni této povinnosti, at' již ze strany pojištovny či cestovni kanceláre, mělo toto porušeni právni povinnosti vést ke zhoršení postaveni spotřebitele. Kromě toho, jak vyplývá z odstavce 3 téhož paragrafu, má pojištovna prostředky $k$ tomu, aby si plněni povinností stanovených cestovní kancelárí zajistila, nebot' má př́stup ke všem dokladům, které souvisejí s pojištěním zájezdi̊ a v prípadě pochybností má možnost žádat vysvětlení. Je navíc svobodnou volbou pojištovny, zda uzavře s cestovní kancelárí přislušné pojištění záruky a za jakých podminek se tak stane, jakýkoli smluvni př́mus (kontraktačni povinnost) zde není. Při srovnáni možností, které dává zákon pojištovně a povinností, které ukládá cestovní kancelárí, je nepředstavitelné, aby mohlo být kladeno k tiži spotřebitele - zákazníka cestovni kanceláre - že se cestovni kancelár snažila vyhnout svým povinnostem k uzavřeni odpovidajicího pojištění, př́ipadně že pojištovna podcenila zjištování pravdivosti údajů poskytnutých cestovni kancelář́.

Zákazník cestovni kanceláre může zjistit pouze to, zda cestovni kancelár̆ má uzavreno pojištěni proti úpadku, nemá však žádnou možnost ověrit, zda toto pojištění je rádné, co je jeho obsahem, př́padně jaké je pojistné krytí. Jedná se o informace, které spotřebitel nejen nemůže mít, ale které jej ani zajímat nemuseji, nebot' právě k ochraně jeho vynaložených prostředkủ je př́slušná právní úprava stanovena. Naproti tomu pojištovna disponuje takovými zákonnými prostředky, které jí proti cestovní kanceláři umožňují, aby svá př́padná rizika minimalizovala. Jako podnikatel dokáže sama na základě přislušných podkladù, které má možnost od cestovni kanceláre vyžadovat, vyhodnotit vhodnost navrhovaného pojištění, jeho rozsah, výši pojistného plnění, cenu takového pojištěni a dalši faktory, jež jsou pro uzavreni pojistky důležité. Šiři smluvní volnosti v daném př́padě podtrhuje i skutečnost, že pojištovně žádný právní předpis neukládá povinnost, aby př́slušnou pojistnou smlouvu s cestovni kanceláři uzavrela a je pouze na ní, za jakých podminek tak učiní. Obsah smluvních ujednání je v rukou smluvnich stran, kterými je pojištovna a cestovni kancelár̆; v př́padě zjištění, že cestovni kancelár uvedla pojišstovně nepravdivé údaje, má pojištovna možnost na tuto 
skutečnost reagovat. Spotřebitel není smluvní stranou této smlouvy, je pouze beneficientem a proto jakákoli smluvni ujednáni mezi dvěma podnikateli nemohou být vykládána k jeho tiži. Pojištovně je z právního předpisu znám účel a smysl pojištěni záruky pro připad úpadku cestovni kancelář (jímž je plná náhrada ceny zájezdu), pročež obrana spočivajicí v nedostatečném rozsahu pojistného kryti vyplývajicím z pojistné smlouvy, kterou sama uzavřela, je zjevně účelově alibistická a dovolává se porušení vlastní právní povinnosti. Z uvedeného dưvodu soud uzavírá, že ani limit pojistného plněni sjednaný mezi smluvními stranami pojistné smlouvy nemũže vést $k$ odmitnutí plněni spotřebiteli, protože ten není smluvni stranou tohoto právniho vztahu, za situace, kdy jeho práva jsou dána zákonem.“

$\mathrm{S}$ argumentací žalované pojištovnny se soud v prvním rozsudku vypořádal následovně:

„Žalovaná především dovozuje, že citovaná směrnice Rady 90/314/EHS byla do českého právního rádu transponována vadně, a proto za závazky cestovni kanceláre má zákaznikưm cestovnich kancelář́ odpovidat stát. $K$ tomuto závěru vede žalovanou výklad judikatury Soudniho dvora Evropské unie a vlastni gramatický výklad př́slušných zákonných ustanovení vnitrostátního práva. Žalovaná sice správně uvádí účel směrnice, kterým je zajištěni efektivni záruky vrácení všech peněz a repatriace spotřebitelì v př́padě insolvence poskytovatele zájezdu, avšak následně bez dalšího vychází z premisy, že tento účel není v přislušných zákonných ustanovení dodržen, když za tuto situaci nenese (zcela prirozeně) odpovědnost pojištovna, [...] avšak samotný český stát..."

V této souvislosti soud uvádí, že povinnost pojišt'ovny plnit za cestovní kanceláŕ v plném rozsahu veškeré pojištěné riziko dovodil logickým, systematickým i teleologickým výkladem shora uvedených právních norem a shledal tak nárok žalobce po právu. Vyplývá-li nárok žalobce z platného práva, nelze hovořit o vadné transpozici příslušné směrnice a přímý účinek takto údajně vadně transponované směrnice tudíž nemůže nastat. Poukaz žalované na rozhodnutí ESD C-140/97 ve věci Walter Rechberger a další proti Rakousku není přiléhavý. V tomto rozhodnutí ESD konstatoval, že není důležité, jakým způsobem je článek 7 směrnice 90/314/EHS proveden, smyslem je, aby byla $\mathrm{v}$ př́padě úpadku cestovní kanceláře spotřebiteli účinně zajištěna zpáteční doprava a vrácení vložených prostředků.

$\mathrm{V}$ př́padě, že by spotřebiteli v důsledku nesprávného provedení čl. 7 směrnice vznikla škoda, mohl by se na členském státu domáhat její náhrady. S uvedenými závěry Soudního dvora nelze než souhlasit, avšak o takový př́ípad se v daném př́ípadě nejedná. Spotřebiteli dosud z titulu údajně vadného provedení směrnice škoda vzniknout nemohla, nebot' nárok zákazníka cestovní kanceláře proti pojištovně byl dovozen výkladem vnitrostátních právních předpisů, kterými byla př́slušná směrnice provedena a dle názoru soudu žádné ustanovení citovaných zákonů nenasvědčuje tomu, že by transpozice směrnice do českého právního řádu nebyla řádná, jak tvrdí žalovaná. Citovaný rozsudek navíc nedává odpověd’ na otázku, zda konkrétní česká vnitrostátní zákonná úprava odpovídá zamýšlenému výsledku, který je sledován předmětnou směrnicí.

Žalovaná se domnívá, že pojistná částka nemůže pokrývat celý závazek cestovní kanceláře vůči jejím zákazníkům s odůvodněním, že to zákon $\mathrm{v} \S 8$ odst. 2 vylučuje stanovením povinnosti cestovní kanceláře sjednat pojištění záruky na pojistnou částku 
v minimální výši 30 \% ročních plánovaných tržeb z prodeje zájezdu, nebo v případě, že tyto tržby mají být nižší než tržby v předchozím roce, na pojistnou částku minimálně $30 \%$ těchto tržeb v předchozím roce. Jak bylo již výše uvedeno, tento právní závěr žalované považuje soud za nesprávný, nebot' zcela pomíjí účel a smysl ochrany spotřebitele, který lze snadno zjistit tradičními metodami výkladu právních norem. Uvedené ustanovení, jak bylo již výše řečeno, směřuje k minimalizaci rizik pojišt’ovny, které je uložena povinnost plnit za cestovní kancelář vše, co by musela cestovní kancelář jinak svým zákazníkům plnit sama. Naopak i pouhým jazykovým výkladem tohoto ustanovení lze dospět $\mathrm{k}$ závěru, že zásada plné náhrady uvedená $\mathrm{v} \S 6$ zákona z pojištění záruky tím není nijak dotčena (viz znění: ,... je povinna sjednat pojištění v rozsahu $§ 6 .$. “). Cestovní kancelář je tudíž povinna sjednat pojištění pokrývající veškeré nároky zákazníků, nikoli jen jejich část, přičemž dle ust. $§ 7$ odst. 3 zákona, v př́padě porušení povinnosti cestovní kanceláře poskytnout pojišt'ovně pravdivé a úplné podklady, je pojišt'ovna beztak povinna plnit v plném rozsahu a proti cestovní kanceláři má nárok na náhradu škody.

Žalovaná se ve své obraně též pozastavila nad údajnou absencí právního titulu k plnění zákazníkům v celém rozsahu, protože tímto titulem je pouze pojistná smlouva. Pokud by bylo plněno nad rámec pojistné smlouvy, bylo by plněno bez právního důvodu. Také tento právní závěr žalované je dle názoru soudu nesprávný. Jak bylo uvedeno výše, pojištění záruky pro případ úpadku cestovní kanceláře musí pokrývat $\mathrm{v}$ celém rozsahu nároky, které by měla svým zákazníkủm plnit sama cestovní kancelár. Právním titulem je tak skutečně pojistná smlouva uzavřená mezi cestovní kanceláří a pojišt'ovnou. Jestliže však tyto smluvní strany uzavřou v rozporu se zákonnou povinností smlouvu nesplňující zásadu plné náhrady, pak právním následkem je v takovém př́ípadě ve smyslu ust. $\S 6$ odst. 3 zákona neplatnost př́slušného smluvního ujednání a právním důvodem plnění je odpovědnost za škodu. V této souvislosti dlužno znovu zmínit, že porušení zákonné povinnosti dvou podnikatelů, tedy „dodavatelů“ ve smyslu $\S 52$ odst. 2 o.z. nemůže jít k tíži zákazníka chráněného spotřebitelským právem. Právní závěr žalované o ,plnění bez právního důvodu“ je tudíž lichý.

Důležitým samostatným argumentem žalované pojišt'ovny bylo, že eurokonformní výklad není ve věci možný, jelikož mu brání povinnost stanovená pojištovně zákonem č. 37/2004 Sb. o pojistné smlouvě. Soud v prvním rozsudku k tomu argumentu zdůraznil, že: ,jakkoli je v citovaném ust. § 6 odst. 2 zákona uvedeno, že: ,není-li tímto zákonem stanoveno jinak, ř́dí se povinné pojištění záruky př́slušnými ustanoveními zvláštního zákona ; a tímto zvláštním zákonem je zákon o pojistné smlouvě, použije se onen zvláštni zákon subsidiárně. Vzájemný vztah obou předpisư je tedy přesně opačný, než by mohlo vyplývat z pouhého gramatického výkladu: obecným je zákon o pojistné smlouvě, speciálním je zákon č. 159/1999 Sb. Právě v tomto zákoně je pak (spolu s př́slušnými ustanoveními hlavy XXI. o. z., které je třeba použivat společně) ono ,stanoveno jinak', což je zminěná povinnost sjednat pojištění záruky v celém rozsahu.“" 


\section{VLNA PROKLIENTSKÝCH ROZSUDKU゚}

První proklientský rozsudek byl bezprostředně následován několika dalšími proklientskými rozsudky Obvodního soudu pro Prahu 2. ${ }^{14}$ Autorka je toho názoru, že jen část těchto proklientských rozsudků vycházela z názorové shody s argumentací naznačenou prvním rozsudkem. $Z$ průběhu jednání před soudem bylo u některých soudců evidentní, že nejsou rozhodnuti a jen se vezou na proklientské „vlně“, která jistou dobu trvala.

Klienti slavili úspěch také před odvolací instancí, tj. před Městským soudem v Praze. Senát 15 Co ve svém rozsudku č.j. 15 Co 471/2013-127 ze dne 18. 2. 2014 rozvedl proklientskou argumentaci Obvodního soudu pro Prahu 2 následujícím způsobem:

„Omezení pojistného plněni dle § 28 odst. 1 a 3 zákona č. 37/2004 Sb., o pojistné smlouvě, či na základě pojistných podminek pojištovny neprichází v úvahu, nebot' by došlo $k$ vyloučení nebo $k$ omezení zákonných nárokủ spotřebitele. Takové ujednání by omezilo právo spotřebitele a popřelo by smysl zákona. Ustanoveni § 8 odst. 2 CestRuch má za cil snižit rizika pojištovny, které je uloženo povinnosti plnit za cestovní kancelár vše, co by jinak musela plnit sama cestovni kancelár̆. V̌̌ádném př́padě však nelze toto ustanoveni vykládat tak, že by mohlo značit sniženi plné náhrady uvedené $v \S 6$ CestRuch. Tomuto závéru nasvědčuje i 7 odst. 3 CestRuch, v němž je uvedeno, že v prípadě porušeni povinnosti CK poskytnout pojištovně pravdivé a úplné podklady, je pojištovna povinna plnit v plném rozsahu a proti CK má nárok na náhradu škody. Je tak zřejmé, že zákon vychází ze zásady plné náhrady uvedené v 6 CestRuch. Je věci pojištovny, aby se ř́dně seznámila s podklady od cestovní kanceláre a na základě nich uvážila, zda s cestovni kancelárí uzavře pojištěni záruky, či nikoliv a jaké budou podminky pojistné smlouvy. Skutečnost, že pojištovna tuto svoji možnost nedostatečně využila nebo že cestovni kancelár neposkytla pojišstovně úplné či pravdivé údaje nemưže být pričctena $k$ tiži spotřebitele, který nemůže obsah pojistné smlouvy ani výši pojistné částky žádným způsobem ovlivnit.

Soud prvního stupně proto zcela správně uzavřel, že výše limitu pojistného plnění sjednaného mezi smluvnimi stranami nemůže být dưvodem pro odmítnutí plnění spotřebiteli, který má nárok na plnění v takové výši, v jaké měla jeho nároky uspokojit cestovní kanceláŕ.“

Rozsudek ve prospěch klientů potvrdil také senát 51 Co Městského soudu v Praze. ${ }^{15}$

\section{ZAMÍTAVÉ ROZSUDKY}

Poté, co se první proklientská vlna převalila, ale přišla vlna zamítavých rozsudků. ${ }^{16}$ Prvním zamítavým rozsudkem, který autorka zaznamenala, byl rozsudek

\footnotetext{
14 Srov. např. rozsudek Obvodního soudu pro Prahu 2, č.j. 11 C 15/2012-98 ze dne 7. 6. 3013, rozsudek Obvodního soudu pro Prahu 2, č.j. 26 C 68/2012-82 ze dne 15. 8. 2013, rozsudek Obvodního soudu pro Prahu 2 ve věci sp. zn. 41 C 68/2012 dne 10. 10. 2013.

15 Srov. rozsudek č.j. 51 Co 38/2014 - 165 ze dne 28. 3. 2014.

16 Rozsudek Obvodního soudu pro Prahu 2 č.j. 13 C 129/2012-91 ze dne 5. 3.2014 nebo rozsudek Obvodního soudu pro Prahu 2 č.j. 10 C 81/2012 - 206 ze dne 25. 3. 2014.
} 
Obvodního soudu pro Prahu 2 č.j. 13 C 129/2012-91 ze dne 5. 3. 2014. Za pozoruhodnou považuje autorka následující argumentační linku rozsudku:

„Soud pouze na okraj poznamenává, že nemohl jít cestou ,eurokonformního výkladu 'zákona ve prospěch žalobkyně jako spotřebitelky, jak požadovala sama žalobkyně, a priziznat jí žalobou požadovanou částku, nebot' by tak skutečnost, že zákonodárce, ač původně měl v úmyslu stanovit minimálni limit pojistné částky ve výši 50 \% ročních plánovaných tržeb z prodeje zájezdů cestovní kanceláré, následně tento limit snižil na pouhých $30 \%$, šla zcela nezákonně k tiži žalované, která by byla př́padným rozhodnutím soudu nucena poškozovat zájmy svých akcionárú i zákazniků (zde v převážné většině rovněž spotřebiteliu) a plnit nad limit sjednanýv v souladu se zákonem (č. 159/1999 Sb. i č. 37/2004 Sb.). Soud uzavírá, že v př́padě, že škody zpưsobené cestovni kanceláří jsou vyšši než sjednaný limit pojistného plněni t.j. pojistná částka, není pojištovna povinna plnit nad tento limit, nebot' ji to neukládá žádné zákonné ustanoveni.“"

V rozsudku Obvodního soudu pro Prahu 2 č.j. 10 C 81/2012 - 206 ze dne 25. 3. 2014 se můžeme navíc dočíst, že:

„Je pravdou, že žalobkyně nebyla smluvní stranou při uzavírání pojistné smlouvy mezi cestovní kancelárí a pojištovnou a tudiž její obsah nemohla ovlivnit. To však žalobkyni nebránilo v tom, aby si sama uzavřela s jakoukoliv pojištovnou samostatně cestovni pojistnou smlouvu (pojišténi pro prípad neuskutečněni zájezdu) a nespoléhala pouze na pojištěni cestovni kanceláre proti úpadku. Ochrana spotřebitele nemǔže být bezbřehá, zvlášt’ za situace, kdy má jiné možnosti jak předcházet vzniku škody. Ochrana spotřebitele též nemůže být tak rozsáhlá, aby popirala dalši právní principy, napřr. princip právní jistoty, $k d y$ žalovaná postupovala při uzavírání pojistné smlouvy v souladu se zákonem a pojistnými podmínkami schválenými dvěma ministerstvy a měla legitimní očekávání, že může být zavázána poskytnout plněni pouze do sjednaného limitu pojistného plnění.

Ve světle vnitrostátního i evropského práva se pak úprava ochrany zákazníků cestovnich kancelárí jeví jako diskriminujicí ve vztahu $k$ jiným spotřebiteli̊m, kteři se dostanou do stejné situace (platební neschopnost jiných podnikatelů než cestovních kancelárí), jejichž práva však nejsou chráněna vi̊bec, ačkoliv se v jejich př́padě může jednat o mnohonásobně vy̌šsi škody (např. při zaplacení celoživotních úspor stavební firmě na stavbu rodinného domu, která se následně dostane do úpadku, dům nepostaví a penize nevrátí).“

Rovněž zamítavé rozsudky získaly své stoupence u některých senátů Městského soudu v Praze. ${ }^{17}$ Ve věci č.j. 53 Co 302/2014-252 ze dne 20. 11. 2014 Městský soud potvrdil zamítavý rozsudek Obvodního soudu pro Prahu 2 s následujícím odůvodněním:

„V prvé řadě nutno poukázat na zcela konkrétni a jakýmkoli výkladem nezpochybnitelné ustanoveni § 6 odst. 1 CestRuch, dle kterého je to cestovni kancelár, kdo je povinen sjednat pojištěni záruky pro př́pad úpadku tak, aby zákaznikovi pro zamýšlené prípady vzniklo právo na plnění uváděná pod pismeny a) až c), pojištovně v tomto směru zákon žádnou povinnost neukládá. Stejná povinnost pak opět a pouze pro cestovní

17 Srov. rozsudek Městského soudu v Praze č.j. 72 Co 79/2014-164 ze dne 21. 5.2014 a rozsudek č.j. 53 Co 302/2014-252 ze dne 20. 11. 2014. 
kancelář vyplývá i z § 8 odst. 2 CestRuch, dle kterého je kancelář povinna sjednat pojištěni v rozsahu § 6 CestRuch na pojistnou částku minimálně $30 \%$ ročnich plánovaných tržeb z prodeje zájezdů nebo v prípadě, že tyto tržby maji být nižši než v předchozím roce, na pojistnou částku minimálně $30 \%$ těchto tržeb v předchozím roce. Vykládat tato ustanovení jakkoli v neprospěch žalované pojištovny, či z nich dovozovat jeji povinnost plnit nad rámec sjednané pojistné smlouvy neprichází v úvahu. Citovaná ustanoveni ve spojeni se správným poukazem na dohledovou a kontrolní činnost ministerstev a ČNB a poukazem na jednoznačné vyjádřeni důvodové zprávy nevzbuzuji žádných pochyb o tom, že zámérem zákonodárce bylo uvedenou úpravou povinnost cestovni kanceláre vůči klientưm jako spotřebitelům pokrýt, a tím zámèr směrnice naplnit, zároveñ tento konkrétni př́pad dokladuje, že se tak stalo měrou nedostatečnou. O nedostatečném včleněni směrnice do našeho právního řádu spolehlivě vypovidá i ujednáni všeobecných smluvnich podminek o pomèrném rozdělení nároků klientů v připadě, že jejich součet přesáhne pojistnou částku. Pakliže tyto pojistné podminky výslovně podléhaji schválení státního orgánu a je dle nich udělována koncese, je zjevné, že předem s možností neúplného, tedy poměrného uspokojování klienti̊ z pojišténi predem počitaji, tedy to, že státní orgán vzal předem na vědomí, že uvedená situace může nastat a byl s tím srozuměn. $Z$ uvedeného nelze dovodit jiný závěr než ten, směrnici nerespektoval v požadovaném rozsahu jejího záméru.

Za zcela správné považuje odvolací soud i závěry soudu prvního stupně o tom, že vztah mezi žalobkyní a žalovanou neni vztahem zákaznika a spotřebitele, ten je dán pouze mezi zákazníkem a cestovni kancelárí, a pokud ta nároky spotřebitele nesplnila $v$ rozsahu, který jí ukládá zákon, nelze tuto povinnost přenášet na pojištovnu.

Napadený rozsudek tak správně uzavřel, že pojištovna postupovala v souladu se zákonnou úpravou, platně sjednala pojistnou smlouvu s pojistným limitem speciálně pro tento prrípad pojištěni zákonem vymezeným jeho minimálni dolni hranicí, a dle této smlouvy rádně uspokojila nárok žalobkyně. Skutečnost, že takové jednání nepostačuje k povinnostem vyplývajicím pro cestovni kancelár ze zákonné úpravy, nelze pojištovně klást $k$ tízi a je pouhým dokladem toho, že zákonodárce pro postup dle smérnice nepoužil dostačujicí zákonný nástroj. Žalobkyně žádá po žalované plnění, které ji neukládá žádný právní predpis ani žádný smluvní vztah a jeji žaloba proto nemůže být dưvodná."

\section{DOVOLÁNÍ A ÚSTAVNÍ STÍŽNOSTI}

Význam sporu pro obě dvě strany způsobil, že obě strany byly připraveny hájit svou pozici v př́padě neúspěchu také cestou mimořádného opravného prostředku, jakým je dovolání, a také cestou ústavní stížnost. Ve sporech, ve kterých autorka vystupuje jako advokátka zastupující klienty cestovních kanceláríi v úpadku, byly postupně podány tři ústavní stížnosti a dvě dovolání.

Jedna ústavní stížnost byla podána žalovanou pojištovnou Generali, která byla na základě pravomocného rozsudku Městského soudu v Praze ze dne 28. 3. 2014, č.j. 51 Co 38/2014-165 (citován výše), povinna zaplatit klientovi cestovní kanceláře doplatek pojistného plnění do plné jím zaplacené ceny zájezdu a uhradit mu náklady soudního řízení. 
Generali se svou ústavní stížností proti citovanému rozsudku neuspěla. Ústavní soud usnesením ze dne 30. 7. 2014, sp. zn. I. ÚS 2334/114, její ústavní stížnost odmítl a k citovanému rozsudku Městského soudu v Praze uvedl, že: „V ústavní stižnosti Ústavní soud však neshledal nic, co by věc posunulo do ústavněprávní roviny. Napadená rozhodnutí jsou pečlivě odi̊vodněna a Ústavní soud neshledává, že by byly projevem svévole, či v extrémním rozporu s principy spravedlnosti."

Citované usnesení ÚS ze dne 30. 7. 2014, sp. zn. I. ÚS 2334/114, naznačilo, že výklad soudu ve prospěch spotřebitele je ústavně př́ípustný. Citované usnesení Ústavního soudu ale v praxi následně nezabránilo Městskému soudu v Praze, aby v jiné obdobné věci rozsudkem ze dne 20. 11. 2014, č.j. 53 Co 302/2014-252, rozhodl pro změnu ve prospěch pojišt'ovny (viz rozsudek citovaný výše).

Podruhé se Ústavní soud spory zabýval na základě ústavní stížnosti klientky cestovní kanceláře podané proti rozsudku Obvodního soudu pro Prahu 2 ze dne 5. 3. 2014, č.j. 13 C 129/2012-91. I tuto ústavní stížnost vedenou pod sp. zn. I. ÚS 1868/14 však stejný senát Ústavního soudu dne 24. 2. 2015 odmítl, jelikož ,nedosáhla svým obsahem ústavní úrovně, tím méně pak úrovně ,mimořádně závažného pochybeni 'obecných soudů, která je v těchto př́padech požadována [...], aby mohla být ústavní stizznost shledána opodstatněnou“. Tím vytvořil poněkud absurdní situaci, která mohla svádět k myšlence, že ústavní je jak rozhodnutí ve prospěch tak rozhodnutí v neprospěch spotřebitele. Ústavní soud v odmítavých usneseních rovněž apeloval na to, aby se k věci vyjádřil Nejvyšší soud, jako orgán, jehož úkolem je sjednocovat judikaturu obecných soudů.

Proto bylo i pro autorku skutečným překvapením, když uprostřed léta 2015, dne 16. 7., Ústavní soud meritorně rozhodl o ústavní stížnosti sp. zn. III. ÚS 1996/1318 proti rozsudku Obvodního soudu pro Prahu 2, č.j. 22 C 68/2012-90 dne 26. 3. 2013, a to tak, že nálezem ústavní stížnost zamítl. ${ }^{19}$

\section{NÁLEZ ÚSTAVNÍHO SOUDU}

Překvapení v podobě meritorního rozhodnutí Ústavního soudu se konalo proto, že třetí senát Ústavního soudu se jinak než jeho kolega vypořádal s posouzením tzv. ústavní bagatelnosti věci. ${ }^{20}$ Ústavní soud v bodě 29 nálezu podotkl, že stěžovatelce se sice nepodařilo prokázat, že by př́pad nebyl po kvantitativní stránce bagatelní, ovšem po kvalitativní stránce podle něj prrípad rozhodně bagatelní není „s ohledem na dopad rozhodnutí Ústavního soudu na právní jistotu a stabilitu práva i uzavíraných smluv aktérů v této oblasti právního styku (stát a jeho dozorové orgány, cestovní kanceláře a cestovni agentury, pojištovny a klienti cestovních kancelář́ jako spotřebitelé), nehledě na di̊sledky, které by mohla nejednotná judikatura obecných soudi̊ vyvolat. Ústavní soud tak ve vztahu k základnímu požadavku stěžovatelky (sub 3) uzavírá, že z výše uve-

18 Z hlediska času šlo vůbec o první podanou ústavní stížností k této problematice.

19 Nález je nyní dostupný také ve výběru judikatury Ústavního soudu jako ÚS 1995/2015.

20 Ústavní soud dal ve své rozhodovací praxi najevo, že v případech bagatelních věcí, u nichž procesní úprava nepřipouští odvolání, jako tomu bylo také v případě rozsudku Obvodního soudu pro Prahu 2, č.j. 22C 68/2012-90 ze dne 26. 3. 2013, je v podstatě - s výjimkou zcela extrémních rozhodnutí obecného soudu ústavní stížnost vyloučena (srov. rozhodnutí ve věci sp. zn. III. ÚS 405/04, [43/2004 Usu.], obdobně další sp. zn. IV. ÚS 695/01, sp. zn. IV. ÚS 248/01, sp. zn. IV. ÚS 8/01). 
dených důvodi̊ je věc s ohledem na svi̊j význam meritorně projednatelná. Současně není bez významu, že bez ohledu na bagatelnost předmětu sporu může s ohledem na pravděpodobnost opakujicich se př́padi̊ mit dopad na její právní pozici (dotčenost stěžovatelky v právu na podnikání podle čl. 26 odst. 1 Listiny), stejně jako na pozici ostatních subjektư v této oblasti (zákaznici-spotrebitelé, pojištovny, cestovní kanceláře a Česká republika jako členský stát Evropské unie z hlediska požadavkü, které na něj její právo klade).“

Skutečnost, že Ústavní soud ústavní stížnost proti proklientskému rozsudku zamítl, znamená, že neshledal v ústavní rovině na napadeném rozsudku Obvodního soudu pro Prahu 2 vady. ${ }^{21} \mathrm{~V}$ nálezu lze přitom identifikovat minimálně pět dílčích důvodů, o které Ústavní soud svůj zamítavý postoj opřel:

- Zaprvé, Česká republika je povinna dodržovat princip ochrany spotřebitele jako princip, na kterém je založeno právo Evropské unie. ${ }^{22}$

- Zadruhé, i pro moc soudní v České republice platí povinnost povinnost interpretovat a aplikovat vnitrostátní právo „eurokonformním“ způsobem, tedy při více výkladových variantách volit tu, jež bude v souladu s právem Evropské unie, v daném př́ípadě zejména v souladu s pravidly stanovenými ve směrnici 90/314. ${ }^{23}$

- Zatřetí, soudní moc České republiky je při použití ustanovení vnitrostátního práva přjiatých za účelem provedení povinností stanovených směrnicí 90/314 povinna přihlédnout $\mathrm{k}$ veškerým pravidlům vnitrostátního práva a vyložit je v co možná největším rozsahu ve světle znění, jakož i účelu směrnice 90/314, aby tak mohlo být dosaženo rozhodnutí, které je v souladu s cílem jí sledovaným. ${ }^{24}$

- Začtvrté, obecný soud splnil uvedené povinnosti, jestliže klientské žalobě vyhověl. ${ }^{25}$

- Zapáté, eurokonformní výklad v dané věci není výkladem contra legem, který ani podle Soudního dvora EU nemůže být přijat s cílem dosažení konformity s unijním právem. Ústavní soud v tomto bodě podotkl, že pojem ,zvláštní předpis“ použitý v § 6 odst. 2 zákona č. 159/1999 Sb., který argumentačně využívá žalovaná, nemusí vždy znamenat totéž co speciální předpis (lex specialis) s následnou nutností před-

21 Srov. bod 52 nálezu: „V této souvislosti Ústavni soud připomíná, že je soudním orgánem ochrany ústavnosti (čl. 83 Ústavy), který stojí mimo soustavu obecných soudi̊ (čl. 91 odst. 1 Ústavy), a že vzhledem $k$ tomu jej nelze, vykonává-li svoji pravomoc tak, že ve smyslu čl. 87 odst. 1 písm. d) Ústavy rozhoduje o ústavní stížnosti proti pravomocnému soudnímu rozhodnutí, považovat za další, ,superrevizní instanci $v$ systému obecné justice, oprávnénou svým vlastnim rozhodováním (nepřimo) nahrazovat rozhodování obecných soudů; jeho úkolem je ,toliko ' přezkoumat ústavnost soudních rozhodnutí, jakož i rízení, které jejich vydání předcházelo. Vzhledem k tomu nutno vycházet z pravidla, že vedení řizení, zjištováni a hodnocení skutkového stavu, výklad,podústavního 'práva a jeho aplikace na jednotlivý př́pad je v zásadě věcí obecných soudů a o zásahu Ústavního soudu do jejich rozhodovací činnosti lze uvažovat za situace, kdy je jejich rozhodování stiženo vadami, které maji za následek porušení ústavnosti (tzv. kvalifikované vady). Jde-li o proces interpretace a aplikace tzv. podústavního práva, ten zpravidla bývá stižen uvedenou vadou, jestliže obecné soudy nezohledni správně (či vi̊bec) dopad některého ústavně zaručeného základního práva (svobody) na posuzovanou věc, nebo se dopustí - z hlediska spravedlivého procesu - neakceptovatelné ,libovi̊le', spočivajíci bud'v nerespektování jednoznačně znějici kogentni normy, nebo ve zjevném a neodi̊vodněném vybočení ze standardů výkladu, jenž je v soudní praxi respektován, resp. jenž odpovidá všeobecně akceptovanému (doktrinálnímu) chápání dotčených právních institutư."

22 Srov. bod 46 nálezu.

23 Srov. bod 47 nálezu.

24 Srov. bod 48 nálezu.

25 Srov. bod 48 nálezu. 
nosti aplikace speciálního ustanovení. A dále uvedl: „Může též, jako v tomto př́padě, znamenat jen to, že ve věcech neupravených zákonem č. 159/1999 Sb. se měl použit již zákon č. 37/2004 Sb., popř. občanský zákonik (stav akcesority a subsidiarity). Avšak ani pro př́pad akcesority a subsidiarity by nebylo možné stanovisko stěžovatelky uplatnit, nebot' by se tím aplikace zákona č. 159/1999 Sb. dostala do rozporu s ústavním pořádkem a unijním právem, jak bylo výše uvedeno." 26

Argumentace Ústavního soudu podle názoru autorky graduje v bodě 52 nálezu, v jehož závěru Ústavní soud jako obiter dictum výslovně uvádí: „[s]toji-li obecný soud pred volbou mezi rovnocennými výkladovými variantami v rovině podústavního práva, je nutno preferovat ústavněkonformni a eurokonformni výklad.“

Ústavní soud rovněž objasnil, že v předmětné věci není důvod k položení předběžné otázky, nebot' se jedná již o otázku Soudním dvorem EU objasněnou (,act elairé“).

\section{ÚKOL PRO NEJVYŠŠÍ SOUD}

Pokud jde o dovolání, za účelem sjednocení judikatury nižších soudů byla k Nejvyššímu soudu ČR již podána nejméně dvě dovolání. $Z$ toho jedno klientem a jedno pojišt'ovnou Generali. Jedná se o dovolání pojištovny Generali proti rozsudku Městského soudu v Praze ze dne 18. 2. 2014, č.j. 15 Co 471/2013-127, které je u Nejvyššího soudu vedeno pod sp. zn. 23 Cdo 4545/2014, a o dovolání klientky cestovní kanceláře proti rozsudky Městského soudu v Praze ze dne 21. 5. 2014, č.j. 72 Co 79/2014-164, které je u Nejvyššího soudu vedeno pod sp. zn. 32 Cdo 139/2015.

Obě dovolání se nicméně týkají částky pod 50000 Kč a je tedy otázkou, zda budou Nejvyšším soudem vůbec přijata. ${ }^{27}$ Autorka by obsah rozhodnutí Nejvyššího soudu nerada předjímala, i když jako advokátka klientů doufá, že Nejvyšší soud, jestliže bude rozhodovat ve věci, vyjde z názoru, který Ústavní soud formuloval ve svém obiter dictum.

\section{DOPADY ROZSUDKU゚}

Přestože na podzim roku 2015, kdy byl sepsán tento článek, ještě právní spor nebyl definitivně vyř̌šen, je nepochybné, že rozsudky, které byly k této problematice od roku 2013 doposud vyneseny, a zejména pak nález Ústavního soudu sp. zn. III. ÚS 1996/13 ze dne 16. 7. 2015, měly významný mediální ohlas, působily silou přesvědčivosti na další soudy rozhodující v obdobných věcech a ovlivňovaly jednání subjektů přímo nebo nepř́mo zúčastněných na sporu, tj. klientů, pojišt’oven, cestovních kanceláŕí i státu, zejména Ministerstva pro místní rozvoj.

26 Srov. bod 51 nálezu.

27 Srov. § 238 odst. 1 písm. c) o.s.r.., podle kterého dovolání není př́ípustné: „proti rozsudkům a usnesením, $v$ nichž dovoláním napadeným výrokem bylo rozhodnuto o peněžitém plněni nepřevyšujicím $50000 \mathrm{Kč \text {, }}$ ledaže jde o vztahy ze spotřebitelských smluv a o pracovněprávni vztahy; $k$ príslušenstvi pohledávky se přitom neprihliží. “Autorka je toho názoru, že výjimka, která se týká vztahů ze spotřebitelských smluv byla zavedena za účelem ochrany spotřebitele, a nikoli $\mathrm{k}$ tomu, aby ji využivali i podnikatelé. 
Spor mezi klienty a pojišt’ovnami byl od počátku v hledáčku všech médií. Zvýšený mediální ohlas mělo přirozeně podání prvních žalob ${ }^{28}$ a poté vynesení prvního rozsudku ve věci, který byl proklientský. Po jeho vynesení autorka poprvé v této věci poskytovala rozhovory do rádia, televize i novin. ${ }^{29}$ Jen některá média následně zachytila skutečnost podání ústavní stížnosti ve věci. Největší mediální ohlas ale přirozeně přineslo vynesení nálezu Ústavního soudu dne 16. 7. 2015. ${ }^{30}$ Mediální sláva nálezu po praktické stránce způsobovala zvýšený počet telefonátů a emailů potenciálních klientů do kanceláře autorky s dotazy, zda stále existuje možnost podat proti pojišt’ovně žalobu. Ze zkušenosti s první vlnou „slávy“ spojené s prvním vítězným mediálně propíraným rozsudkem již autorka věděla, že vlna dotazů opadá přibližně po čtrnácti dnech, což se potvrdilo.

\section{DOPAD NA ROZHODOVACÍ ČINNOST SOUDŮ}

Výše bylo uvedeno, že první proklientský rozsudek spustil na nějaký čas vlnu dalších proklientských rozsudků. Soudy se tedy zejména v případě, že se svým rozhodnutím váhaly, rády nechaly inspirovat svým rozhodným kolegou. Tento fenomén ovšem opadl poté, co se objevily rozsudky pro jednu i pro druhou stranu.

Po právní stránce největší ohlas by měl být spojen s nálezem Ústavního soudu. Právo České republiky sice není precedenčního charakteru, a ani nálezy Ústavního soudu v tom směru nejsou vyjímkou, ${ }^{31}$ přesto lze očekávat, že argumentace Ústavního

28 Srov. např. Klienti zkrachovalé cestovní kanceláře chtějí zpět sto procent ceny. Dostupné z: http:// zpravy.aktualne.cz/finance/bez-dovolene-i-bez-penez-klienti-zaluji-pojistovnu/r $\sim$ i:article:739775/ [cit. 15. 11. 2015]. Klienti Parkam Holidays se chtějí soudit o odškodné. Dostupné z: http://archiv.ihned.cz /c1-55016060-klienti-parkam-holidays-se-chteji-soudit-o-odskodne [cit. 15. 11. 2015].

29 Srov. např. Soud poprvé přikázal pojištovně zaplatit plnou cenu za zrušený zájezd. Dostupné z: http://ekonomika.idnes.cz/lide-dostanou-plnou-nahradu-za-zrusenou-dovolenou-f8z-/ekonomika. aspx?c=A130328_213325_ekonomika_brd [cit. 15. 11. 2015]. Pojištovny nesmí krátit plnění klientům zkrachovalých cestovek, rozhodl soud. Dostupné z: http://www.rozhlas.cz/zpravy/politika/_zprava/pojistovny-nesmi-kratit-plneni-klientum-zkrachovalych-cestovek-rozhodl-soud--1193705?print=1 [cit. 15. 11. 2015]. ACK ČR: Rozsudek ohledně odškodnění klienta pojištovnou potvrzen. Dostupné z: http://www.ackcr.cz/tiskove-zpravy/rozsudek-ohledne-odskodneni-klienta-pojistovnou-potvrzen/ [cit. 15. 11. 2015].

30 Srov. např. Náhradu zájezdu lze žádat čtyři roky po krachu cestovky. Dostupné z: http://zpravy.e15.cz /domaci/udalosti/nahradu-zajezdu-lze-zadat-ctyri-roky-po-krachu-cestovky-1212090\#utm_medium=selfpromo\&utm source=e15\&utm campaign=copylinkhttp://zpravy.e15.cz/domaci/udalosti/nahradu-zajezdu-lze-zadat-ctyri-roky-po-krachu-cestovky-1212090 [cit. 15. 11. 2015]. Pojišt'ovny by podle ÚS měly v př́padě krachu cestovní kanceláře vyplácet celou cenu zájezdu. Dostupné z: http://www.rozhlas.cz/zpravy /politika/_zprava/pojistovny-by-podle-us-mely-v-pripade-krachu-cestovni-kancelare-vyplacet-celou-cenu -zajezdu--1514408 [cit. 15. 11. 2015]. Podle Ústavního soudu by pojišt'ovny měly po krachu vyplácet celou cenu zájezdu. Dostupné z: http://www.bulletin-advokacie.cz/podle-ustavniho-soudu-by-pojistovny-mely-po-krachu-vyplacet-celou-cenu-zajezdu?browser=mobi [cit. 15. 11. 2015]. Při krachu cestovky musí pojištovna zaplatit vše, řekl soud. Dostupné z: http://zpravy.aktualne.cz/finance/pri-krachu-cestovky-musi-pojistovna-zaplatit-vse-rekl-soud/r 8c6c1d582fa811e5b4780025900fea04/ [cit. 15. 11. 2015].

31 Nejvyšší soud ČR se dokonce proti absolutní závaznosti nálezů Ústavního soudu vymezil usnesením sp. zn. 5 Tz 250/2001, v němž uvedl: ,Pro obecné soudy až dosud není upravena a neexistuje jakákoliv závaznost nálezů Ústavního soudu pro jejich rozhodováni, pokud nejde o rozhodování ve věci, v niž Ústavní soud již zrušil rozhodnutí obecného soudu a vyslovil prítom právní názor o tom, které úkony a doplnění 
soudu bude působit silou přesvědčivosti. Ke dni sepsání tohoto článku, tedy v relativně krátké době po vydání nálezu, už ostatně autorka zaznamenala ve dvou věcech rozsudek ve prospěch klientů s odkazem na nález Ústavního soudu. ${ }^{32}$

\section{PRAKTICKÝ DOPAD NA JEDNÁNÍ DOTČENÝCH SUBJEKTU゚}

Pojišt'ovny byly po celou dobu trvání sporu konzistentní ve své argumentaci zastávané před soudem a důsledně ji respektovaly $\mathrm{v}$ komunikaci s klienty, kteří se na ně obraceli $\mathrm{s}$ žádostmi a předžalobními výzvami, ale také $\mathrm{v}$ komunikaci s cestovními kancelářemi, státem i médii.

Pojištovna Generali navíc již v roce 2012 vytáhla do boje zavedením zcela nového typu pojištění, tzv. cestovní pojištění pro př́ípad neuskutečnění zájezdu, které mělo suplovat pojištění záruky pro případ úpadku, jelikož zákon č. 159/1999 Sb., podle pojišt'oven neochrání klienty dostatečně. ${ }^{33}$

Na postoji pojišt’oven nic nezměnil ani nález Ústavního soudu v červenci 2015. Na základě několika nových klientských výzev k plnění se autorka od pojištovny dozvěděla, že pojištovna sice rozhodnutí Ústavního soudu respektuje, ale pouze v daném projednávaném př́padě klienta zkrachovalé cestovní kanceláře I. Parkam Holidays. Pokud jde o plnění v dalších případech je pojišt'ovna toho názoru, že:

„proti Nálezu Ústavniho soudu, jenž sám zdůrazňuje, že není nejvyšši instatncí soudního ř́zení, stojí rozporná, i opačná rozhodnutí obecných soudù. Musíme vzít v úvahu, že působnost $k$ sjednocení judikatury svěřuje Nejvyššimu soudu České republiky (ust. $\S 14$ zákona č. 6/2002 Sb.), nikoli soudu ústavnimu. Konečně jsme povinni respektovat i zákonný př̀kaz, ukládajici pojištovnám obezřetnost při podnikáni. To predevším zahrnuje respekt k právním normám, jež pojištovnictví reguluji. Požadavek na poskytnutí pojistného plněni nad rámec sjednaného pojistného limitu však neni dle našeho názoru v souladu s právnimi povinnostmi pojištoven vyplývajicimi zejména ze zákona o pojištovnictví a zákona o pojistné smlouvě. Podle ustanovení § 8 odst. 2 zákona č. 159/1999 Sb., o některých podmínkách podnikání a o výkonu některých činností $v$ oblasti cestovniho ruchu je zákonnou povinností cestovni kanceláre sjednat pojištění za pojistnou částku minimálně $30 \%$ ročnich plánovaných tržeb z prodeje zájezdů nebo $v$ prípadě, že tyto tržby mají být nižši než tržby v predchozím roce, na částku minimálně 30 \% těchto tržeb v predchozím roce. Pojistná smlouva výše uvedené cestovní kanceláre byla uzavřena na základě cestovnich kanceláři doložených údajů plněv souladu s platnými predpisy České republiky.

Pojistná smlouva se mj. ř́dí ustanoveními zákona č. 37/2004 Sb., zákon o pojistné smlouvě. Podle ustanovení § 28 zákona č. 37/2004 Sb., o pojistné smlouvě je pojist-

je obecný soud povinen provést. Soudci obecných soudu jsou při výkonu své funkce nezávisli a jejich nestrannost nesmí nikdo ohrožovat (čl. 82 Ústavy) a soudce je při rozhodování vázán zákonem (čl. 95 odst. 1 , věta před střednikem Ústavy). “Rovněž Ústavní soud se v nálezu sp. zn. III. 127/96 vyjádřil, že ,si je dobře vědom, že rozhodnutí o ústavní stižnosti zavazuji pouze pro daný prípad a nemaji precedenční povahu“.

32 Srov. rozsudek Obvodního soudu pro Prahu 8 č.j. 12 C 230/2013-227 ze dne 24. 9.2015 a rozsudek Obvodního soudu pro Prahu 8 ve věci sp. zn. 30 C 230/2013 ze dne 11. 11. 2015.

33 První cestovní pojiššení pro př́ipad neuskutečnění zájezdu. Dostupné z: http://www.generali.cz/tiskove-zpravy/prvni-cestovni-pojisteni-pro-pripad-neuskutecneni-zajezdu [cit. 15. 11. 2015]. 
né plněni pojistitele omezeno horni hranicí, tedy limitem pojistného plnění. Odst. 3 téhož paragrafu stanoví, že limit pojistného plněni se stanoví na návrh pojistnika, v tomto př́padě tedy cestovní kanceláre. Pojištovna neni oprávěna určit limit pojistného plněni ani kontrolovat jeho dostatečnost z hlediska objemu možných závazkủ cestovni kanceláře.

Protože limit pojistného plnění, který si sjednala cestovni kancelár̆, nebyl dostatečný pro úhradu nároků vznesených jejími klienty v plné výši, plně v souladu s pojistnými podmínkami a pojistnou smlouvou, vyplatila Generali Pojištovna a.s. pojistné plnění jednotlivým klientům cestovni kanceláre poměrně. Výše poskytnutého plněni odpovídá poměru cestovni kancelář́ sjednaného limitu pojistného plnění vůči součtu všech vznesených oprávněných nároků jejích klientů. " ${ }^{43}$

Jinými slovy, pojišt'ovna stále odmítá plnit jinak než oproti pravomocnému rozsudku, který jí ukládá povinnost k plnění ve stanovené výši.

Spory zcela jednoznačně podnítily Ministerstvo pro místní rozvoj k přípravě novely zákona č. 159/1999 Sb. ${ }^{35}$ Navrhované změny textu směrovaly jednoznačně k odstranění výkladových pochybností o tom, že existuje povinnost pojištoven ke stoprocentnímu plnění. ${ }^{36}$ Byt' byla př́íprava novely využívána pojišt'ovnami v řízeních před soudem jako důkaz o tom, že platná a účinná novela se stoprocentním plněním nepočíá, Ministerstvo pro místní rozvoj od počátku sporů trvalo na tom, že je tomu jinak. ${ }^{37}$ Nález Ústavního soudu pravděpodobně přispěl $\mathrm{k}$ tomu, že Poslanecká sněmovna předloženou novelu dne 16. 9. 2015 v navrhovaném znění schválila. ${ }^{38}$ Předložená novela zákona nakonec nebyla schválena v navrhovaném znění. Ministerstvo pro místní rozvoj relativizovalo svi̊j několik let trvající postoj a v průběhu projednávání návrh novely Senátem připustilo omezení pojistného plnění a přislíbilo vytvoření tzv. garančního fondu. ${ }^{39}$ Důvody $\mathrm{k}$ tomuto postupu však leží v politické rovině, zcela mimo rámec probíhajících soudních sporů. ${ }^{40} \mathrm{Z}$ pohledu dlouholetých klientských sporů je náhlá změna pozice Ministerstva pro místní rozvoj nekoncepční a pro klienty spíše skličující.

34 Vyjádření Pojišt’ovny Generali k předžalobní výzvě klienta ze dne 14. 9. 2015.

35 Text novely předložený vládou Poslanecké sněmovně Parlamentu České republiky je dostupný jako sněmovní tisk 276/0, část č. $1 / 6 \mathrm{z}$ http://www.psp.cz/sqw/text/tiskt.sqw?O=7\&CT=276\&CT1=0 [cit. 7. 2. 2015].

36 Viz navrhované znění $\S 6$ zákona o cestovním ruchu, který ještě podle sněmovního tisku č. 276, který schválila Poslanecká sněmovna, zněl: ,pojistný limit nesmí být nižši než 30 \% ročnich plánovaných tržeb z prodeje zájezdĩ nebo v př́padě, že tržby maji být nižši než tržby v předchozím roce, minimálně $30 \%$ těchto tržeb v predchozim roce, přičemž tento limit pojistného plnění musí být sjednán tak, aby v prípadě pojistné události, kterou je úpadek cestovni kanceláré, byly uspokojeny všechny nároky zákaznikư“.

37 Ministerstvo pro místní rozvoj ostatně poskytlo žalobcům v soudních řízeních v tomto smyslu své stanovisko.

38 Tisková zpráva MMR ze dne 16. 9. 2015: Ochrana spotřebitelů na prvním místě. Dostupná z: http://www .mmr.cz/cs/Ministerstvo/Ministerstvo/Pro-media/Tiskove-zpravy/2015/Novela-MMR-ochrani-klienty-nepoctivych-cestovek [cit. 15. 11.2015].

39 Tisková zpráva MMR ze dne 25. 10. 2015 Ochrana trhu i spotřebitelů v cestovním ruchu je zachována. Dostupná z: http://www.mmr.cz/cs/Ministerstvo/Ministerstvo/Pro-media/Tiskove-zpravy/2015/Ochrana -trhu-i-spotrebitelu-v-cestovnim-ruchu-je-zachovana [cit. 15. 11. 2015].

40 V souvislosti s nálezem Ústavního soudu ze dne 16. 7. 2015 a s připravovanou novelou zákona č. 159/1999 Sb. se desítkám cestovních kanceláŕí na podzim roku 2015 dostalo od jejich pojištoven nepř́ijemného sdělení, a sice obdrželi oznámení o výpovědi jejich pojistné smlouvy s následujícím odůvodněním: „novela zákona 159/1999 Sb., která byla dne 16. 9. 2015 v Poslanecké sněmovně Parlamentu České republiky schválena, ukládá pojištovnám povinnost poskytovat pojišténi záruky pro př́pad úpadku cestovní kanceláře bez jakéhokoli limitu pojistného plnění. Tato změna však zcela odporuje základním principưm pojištění. 


\section{ZÁVĚR}

Od roku 2012 doposud trvá spor mezi klienty cestovních kanceláŕí, které se ocitly v úpadku, a pojišt'ovnami, které popírají, že by měly v situaci, kdy byla cestovní kancelář podle jejich slov „podpojištěna“, vyplácet klientům pojistné plnění ve výši plné ceny zaplacené cestovní kanceláŕi za zájezd. Jedná se o čistě právní spor, kterému je však věnována nezanedbatelná mediální pozornost a který má praktické dopady na jednání jím př́mo nebo nepřímo dotčených osob, tj. klientů, pojištoven, cestovních kanceláŕí i státu, zejména Ministerstva pro místní rozvoj. Praxe ukázala, že soudy, byt' podléhají jistým názorovým vlnám, nejsou jednotny v posouzení právní otázky na pozadí sporu. A to platí nejen pro soudy na úrovni nejnižších instancí, ale také pro úroveň odvolací, ba co víc, i pro různé senáty Ústavního soudu.

Spory jsou velice zajímavé z pohledu unijního práva, jelikož řešení právní otázky je závislé na rozsahu aplikace unijního práva ve věci. Jednotlivé rozsudky jsou sondou do schopnosti českých soudů vykládat právo ČR, v konkrétním př́ípadě zejména zákon č. 159/1999 Sb., eurokonformně, tj. v souladu s cílem a účelem směrnice 90/314. $\mathrm{V}$ tomto ohledu rozsudky prvoinstančních soudů poukazují na jistou nevyrovnanost soudů, pokud jde o pochopení unijního rozměru sporu. Zatímco některé soudy neměly s pochopením požadavku vyložit právo ČR v souladu se směrnicí problémy, jiné nepochopily, že úlohou soudu ČR není posuzovat, zda požadavky, které na ČR klade směrnice, jsou př́ipustné.

Spory byly od počátku sledovány všemi médii a postupně se informace o jejich průběhu stala jakýmsi evergreenem. Nejinak tomu bude minimálně v následujícím roce, jelikož ani nález Ústavního soudu s pravděpodobností hraničící s jistotou nebyl posledním rozhodnutím ve věci. Nyní můžeme s napětím očekávat, zda Nejvyšší soud bude názorově ve shodě s Ústavním soudem přesvědčen, že cesta eurokonformního výkladu je nutná a nedává v konkrétním př́ípadě jinou možnost než žalobám klientů vyhovět.

Bez ohledu na postup soudů ve věci se sporné téma bude dozajista i v budoucnu skloňovat, jelikož Ministerstvo pro místní rozvoj, které v reakci na vznik sporů začalo již v roce 2012 připravovat novelu zákona o cestovním ruchu, jejímž cílem bylo ponechat břemeno stoprocentního plnění na pojištovnách, v samém závěru legislativního procesu ustoupilo tlaku pojištoven a cestovních kanceláří. Je však pochopitelné, že cestovní kanceláŕe se poté, co pojištovny reagovaly na nález Ústavního soudu a na schválení návrhu novely Poslaneckou sněmovnou, výpověd’mi pojistných smluv, cítily existenčně ohroženy, a tedy tlak, který vytvořily na Senát, byl enormní. Návrh novely zákona č. 159/1999 Sb. v podobě odsouhlasené Senátem již tedy počítá s omezením pojistného plnění výší stanoveného limitu pojistného plnění. Pokud jde o aktuální znění zákona, který se použije na všechny běžící spory, setrvává Ministerstvo na svém stanovisku, že ten stanoví povinnost pojištoven ke stoprocentnímu plnění.

V rozsahu a za podminek stanovených touto novelou zákona nebudeme schopni toto pojištěni nadále poskytovat tak, abychom vždy plně zaručili splněni zákonné povinnosti jednat s odbornou péčí a postupovat obezřetně. Pokud v dalšim legislativním procesu dojde ke změnám, které by nám umožnily v provozování tohoto pojištěni pokračovat, můžeme se vrátit k jednáni o dalši spolupráci s Vámi v této oblasti. “Citovaný text byl použit z klientského spisu autorky. 
Zdá se, že Ministerstvo pro místní rozvoj aktuálně nemá připravenu legislativu ani další nástroje $\mathrm{k}$ vytvoření garančního fondu, nebo jiného nástroje, který bude klienty uspokojovat nad rámec plnění poskytnutého z pojišstění záruky pro př́ípad úpadku. Jistěže ideálně by př́padů, kdy plnění nebude dostačovat, mělo být $\mathrm{v}$ budoucnu méně, a to také proto, že by pojištovny měly být poučeny z předchozích nezdarů a jednat $\mathrm{s}$ odbornou péčí, k čemuž jsou povinny. Praxe je ale plná překvapení, a proto autorku nepřekvapí, když do doby, než stát garanční fond nebo jiný nástroj vytvoří, se ocitne $\mathrm{v}$ úpadku další cestovní kancelár. Situace bude pak po právní stránce ulehčena tím, že již bude evidentní, že tito zákazníci se mají obracet se svými nároky prímo na stát s žádostí o náhradu škody.

Právě s ohledem na nedávný legislativní vývoj hodnotí autorka vývoj celé sporné problematiky spíše hořce. Přes úspěchy klientů v několika jednotlivých prŕípadech, kde se klientům podařilo dosáhnout pravomocného rozsudku ve svůj prospěch a výplaty požadovaného plnění, což autorka vnímá i jako svůj profesní úspěch, je zřejmé, že stát ani po čtyřech letech sporů neposkytl klientům nástroj jak př́močaře, tj. aniž by se sami přičinili žalobou, získat plnění, na které mají podle směrnice 90/314 nárok.

Navíc, v př́padech, které byly skončeny pravomocně v neprospěch klientů, bude uplatnění nároku klienta na náhradu škody proti státu ještě procesně problematické. V některých př́ípadech totiž nedošlo ke zrušení pravomocného zamítavého rozsudku, což komplikuje postup klientů podle zákona č. 82/1998 Sb., o odpovědnosti za škodu způsobenou při výkonu veřejné moci rozhodnutím nebo nesprávným úředním postupem. Soudní dvůr Evropské unie je v tomto ohledu naštěstí vždy o krok napřed a koncepční nástroje $\mathrm{k}$ ochraně práv nejen spotřebitelů vytváríi. Pozitivní tečkou na závěr je tedy pro autorku a snad i pro některé dosud neúspěšné klienty, rozsudek Soudního dvora EU ve věci C-160/14 Ferreira da Silva. ${ }^{41}$

Poznámka: Článek byl zpracován v listopadu 2015, další změny zejména z konce června 2016 již nejsou zachyceny.

JUDr. Klára Dvořáková (rozená Havlíčková), M.A.

Holubová advokáti s.r.o.

klara.dvorakova@holubova.cz

41 Rozsudek SDEU C-160/14, EU:C:2015:565 v tomto rozsudku mimo jiné uvedl: „Unijní právo, a zejména zásady vyslovené Soudním dvorem v oblasti odpovédnosti státu za újmu způsobenou jednotlivcům porušením unijniho práva vnitrostátním soudem, jehož rozhodnutí nelze napadnout opravnými prostředky podle vnitrostátniho práva, je třeba vykládat v tom smyslu, že bráni vnitrostátním právním predpisưm, které vyžaduji predchozi zrušeni rozhodnutí, jež způsobilo újmu a které vydal tento soud, třebaže takovéto zrušení je prakticky vyloučeno." 